\title{
Efficient use of energy resources in the context of sustainable development of the pulp and paper industry of Ukraine
}

\author{
Halyna Kupalova ${ }^{1}$, Anzhela Ignatyuk $^{1}$, Nataliia Goncharenko ${ }^{1,{ }^{*}}$, Uliana Andrusiv ${ }^{2}$, and Yuliana Kopetska $^{1}$ \\ ${ }^{1}$ Taras Shevchenko National University of Kyiv, 60 Volodymyrska Str., Kyiv, 01033, Ukraine \\ ${ }^{2}$ Ivano-Frankivsk National Technical University of Oil and Gas, 15 Karpatska Str., Ivano-Frankivsk, 76019, Ukraine
}

\begin{abstract}
The article is devoted to the problem of increasing the efficiency of using energy resources of enterprises of the pulp and paper industry in Ukraine. It has been determined that the pulp and paper industry belongs to energy-intensive types of economic activity. Based on the results of the correlation and regression analysis, a connection was revealed and an economic and mathematical model was formed of the dependence of energy costs for the production of 1 ton of paper on the productivity of paper machines, equipment wear and the volume of investments in energy saving measures. Application of the proposed model will improve information support for the analysis of the effectiveness of energy saving measures, forecasting energy costs and strategic energy management in general. It was carried out at pulp and paper mills, the main obstacles to replacing fossil fuels with biomass in heat production were identified. This made it possible to develop a scientific and organizational model for the energy modernization of enterprises in the pulp and paper industry. It includes financial, organizational, environmental, regulatory, technological, scientific and educational tools. Their application at management will help improve the infrastructure of enterprises in terms of the use of renewable energy resources.
\end{abstract}

\section{Introduction}

The pulp and paper industry plays an important role in the economy, in meeting social needs and in the implementation of low carbon energy systems, but it is an energy intensive activity. According to the Technological Map of the European Strategic Plan for Energy Technologies, the average energy costs in the pulp and paper industry of the European Union countries are from 16 to $30 \%$, and in Ukraine they measure up to $40 \%$ [25]. In 2018, in the production of paper and cardboard in Ukraine, they used 65,8 million $\mathrm{m}^{3}$ of water, emitted 256 million tons of carbon dioxide into the atmosphere, and discharged 254 million $\mathrm{m}^{3}$ of wastewater [20].

Reduction of energy costs in the pulp and paper industry of Ukraine, bringing them to the average European level are especially relevant in the context of adaptation to environmental changes caused by the global pandemic Covid-19. In particular, energy efficiency is an important reserve for reducing operating costs, which, in turn, can to be directed for maintenance of financial stability in the conditions of decrease in demand for production, disturbance of supply chains, growth of logistic expenses. Therefore, increasing the efficiency of the use of energy resources is a priority task to ensure sustainable development, maintain market positions, increase the competitiveness of pulp and paper enterprises in the context of the introduction of European environmental, technical and energy standards.

\section{Literature review}

Scientists of various fields of scientific activity are engaged in solving the problem of increasing the efficiency of the use of energy resources. Talita Mariane Cristino, Antonio Faria Neto and Antonio Fernando Branco Costa [1] have compiled and systematized scientific publications on energy efficiency in buildings. In their opinion, the greatest contributions were made by scientists from the United States, China and the United Kingdom, namely from the Lawrence Berkeley National Laboratory, the Hong Kong Polytechnic University and City University of Hong Kong.

Honggang Zhang, Andreas Gladisch, Mario Pickavet, Zhifeng Tao and Werner Mohr [2] substantiated that the current stage in the development of the information society is accompanied by a rapid growth in energy demand and consumption. This entails certain difficulties in terms of energy supply. In particular, the unprecedented expansion of wired and wireless networks has led to significant increases in energy consumption and a significant environmental footprint. Therefore, the energy costs of mobile service providers (operators) can reach half of the annual operating costs. In these conditions the introduction of energy management system and development of innovative solutions in the field of energy efficiency is especially important. Technologies for efficient energy distribution are being actively developed in the introduction of a sound DLT and IoT system, which

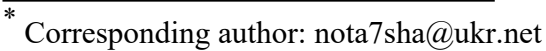


in the future will lead to increased energy efficiency. Therefore, it is important to combine the development of technological innovations with energy efficient technologies.

Khan et al [3] argue that the quality of the environment in the long run depends on the consumption of natural resources and renewable energy. Researchers have proposed policies that control the overuse of natural resources, promote sustainable living and set an environmental budget to ensure the country's sustainable development.

António Cardoso Marques, José Alberto Fuinhas, Carla Tomás [4] formulated a hypothesis that investments and organizational measures in the field of energy efficiency contribute to the sustainable development of the country's economy in general and the energy sector in particular. To prove the hypothesis, scientists have applied the ARDL model, which allows analyzing shortand long-term relationships for upward and downward movements of variables. For the analysis, indicators of the development of the industrial sector of 11 countries of the European Union from 1997 to 2015 were used. The results obtained indicate that investments increase energy efficiency in industrial enterprises, while reducing greenhouse gas emissions. At the same time, economic growth, in turn, directs the economy towards greater energy efficiency.

Saffet Akdag and Hakan Yildirım studied the relationship between energy efficiency and greenhouse gas emissions through panel cointegration, panel causation, and FMOLS and DOLS analysis [5]. Using data from the European Union for 1995-2016, the authors also concluded that there is a close relationship between energy efficiency and greenhouse gas emissions. In particular, greenhouse gas emissions decrease with increasing energy efficiency. Maozhi Chen, Avik Sinha, Kexiang, Hu Muhammad, Ibrahim Shah [6] studied the impact of technological innovation on energy efficiency and sustainable development in the context of the "Fourth Industrial Revolution". Scientists claim that in the era of Industry 4.0, energy efficiency issues can be crucial in terms of sustainable development. The authors analyzed the dependence of the above economic factors on the example of the Middle East and North Africa (North African Republic of the Middle East) during 1990-2016.

Shuaiyin Ma, Yingfeng Zhang Yang Liu, Haidong Yang, Jingxiang Lv and Shan Ren [7] argue that the circular economy plays an important role in energyintensive industries, since it is aimed at sustainable development of society. Scientists believe that in the context of Industry 4.0, advanced technologies (e.g., cloud computing, Internet of things, cyber-physical system, digital twin and big data analytics) provide numerous opportunities for implementing cleaner production strategies and developing smart manufacturing.

Burlov et al. [8] developed a mathematical model for managing the energy sector of the region, which was based on three main system-forming indicators describing the social, economic and ecological systems. Cosmi et al. [9] suggested using the R-MARKAL model to study the possibility of using renewable sources for the production of electricity and heat. Beyzanur Cayir Ervural, Selim Zaim and Dursun Delen [10] proposed a two-stage analytical methodology for assessing energy efficiency (a combination of different energy sources, mainly based on renewable sources) in Turkey.

Incekara and Ogulata [11] show that the main goal of optimal energy distribution is to reduce the cost of energy production, create a minimum impact on the ecosystem and use uninterrupted, clean energy sources under the light of the UNFCCC and the Kyoto Protocol. Ukrainian scientists $[12,13]$ have proposed models for providing the Ukrainian economy with energy resources, in particular, electricity and natural gas. At the same time, many scientists [14, 15] are exploring the issue of the relationship between the policy of reliable energy supply and environmental safety and sustainable development. Yemelyanov et al. [16] and Andrusiv et al. [17] argue that the economic growth of the national economy directly depends on the efficient consumption of energy resources. Conditions are modeled under which economic growth is accompanied by a decrease in the level of dependence of the economy on energy imports. Semerikov et al. [18] in their work consider the impact of the COVID-19 pandemic on the sustainable development of the national economy.

Despite the previous scientific results, energy efficiency and energy modernization of production remain relevant for most sectors of the economy and are of particular importance for Ukraine in connection with the proclaimed European Green Deal.

Therefore, the purpose of the article is to develop theoretical foundations and practical recommendations for increasing the efficiency of energy resources use at the pulp and paper industry in the context of environmental modernization of production and the introduction of alternative energy sources at enterprises.

\section{Research methods}

To achieve the goal of the study, traditional methods of economic analysis were used, in particular, statistical, mathematical, sociological. Thus, the volume and trends in the use of energy resources in the pulp and paper industry of the countries of the European Union and Ukraine were studied using the series of dynamics, comparison, average values and groupings. The methods of correlation and regression analysis made it possible to identify factors affecting the efficiency of energy resource use, to establish a relationship between energy costs per 1 ton of paper and the productivity of paper machines, equipment wear and the level of investment in energy saving measures. To identify obstacles to the use of biomass for the production of heat energy at the pulp and paper industry, a SWOT analysis and an expert survey of industry specialists were carried out. The experts were 26 top and middle managers in the field of energy management (chief engineers -18 people, heat and power engineers -3 people, specialists in the field of energy management -5 people) who work at the pulp and paper industry. The modelling method was used in the development of a scientific and organizational model of 
energy production modernization aimed at increasing the efficiency of energy resources use.

\section{Results and discussion}

\subsection{The state and dynamics of energy consumption at the enterprises of the pulp and paper industry}

The pulp and paper industry is an energy-intensive sector of the economy. Consumption of energy resources in this area in 2017 was $2.4 \%$ in Ukraine, $5.6 \%$ in the EU, $6.8 \%$ in the United States and Canada, and 9.4\% in China of their total industrial consumption [19].

The dynamics of consumption of energy resources in the pulp and paper industry of individual countries of the European Union and Ukraine is different. In 2018, among the countries of the European Union, Finland consumed more energy resources in the pulp and paper industry 6245.8 thousand tonnes of oil equivalent (toe), Germany - 5691.6 thousand toe, France - 2398.4 thousand toe and Great Britain - 1817.6 thousand toe. During 2010-2017, the average annual growth rate of energy consumption in the pulp and paper industry in Hungary amounted to 14.2 thousand toe, or $7.0 \%$, Poland -46.1 thousand toe or $2.82 \%$, Portugal -0.9 thousand toe or $0.1 \%$, Belgium 6.3 thousand toe or $0.9 \%$, Great Britain -46.9 thousand toe or $2.8 \%$. At the same time, the average annual consumption of energy resources in the pulp and paper industry decreased in Denmark - by 190.0 thousand toe or $1.5 \%$, in Germany - by 32.8 thousand toe or $0.6 \%$. France - by 86.7 thousand toe or $3.3 \%$, Spain - by 28.2 thousand toe or $3.6 \%$. In the pulp and paper industry of Ukraine, the consumption of energy resources in the period under review decreased by 36 thousand toe or $12.9 \%$ (Table 1).

Table 1. Dynamics of consumption of energy resources by enterprises of the pulp and paper industry in Ukraine and some EU countries, 2014-2018, thousand toe $([19,20])$.

\begin{tabular}{|c|c|c|c|c|c|c|c|c|}
\hline \multirow{2}{*}{ Country } & \multirow{2}{*}{2014} & \multirow{2}{*}{2015} & \multirow{2}{*}{2016} & \multirow{2}{*}{2017} & \multirow{2}{*}{2018} & \multicolumn{3}{|c|}{ on average for 2014-2018 } \\
\hline & & & & & & absolute increase & growth rate, $\%$ & rate of increase, $\%$ \\
\hline Finland & 5886 & 5936 & 5881 & 6060 & 6245,8 & 90.0 & 101.5 & 1.5 \\
\hline Germany & 5823 & 5821 & 5672 & 5542 & \begin{tabular}{|l|}
5691,6 \\
\end{tabular} & -67.2 & 99.4 & -0.6 \\
\hline France & 2745 & 2384 & 2310 & 2369 & 2398,4 & -86.7 & 96.7 & -3.3 \\
\hline$\overline{\mathrm{UK}}$ & 1630 & 1629 & 1624 & 2082 & 1817,6 & 46.9 & 102.8 & 2.8 \\
\hline Spain & 2052 & 1800 & 1681 & 1645 & 1764,9 & -71.8 & 96.3 & -3.7 \\
\hline Poland & 1571 & 1552 & 1568 & 1637 & 1755,2 & 46.1 & 102.8 & 2.8 \\
\hline Portugal & 1405 & 1311 & 1351 & 1367 & 1408,7 & 0.9 & 100.1 & 0.1 \\
\hline Belgium & 715 & 707 & 737 & 708 & 740,3 & 6.3 & 100.9 & 0.9 \\
\hline Hungary & 182 & 196 & 190 & 205 & 238,9 & 14.2 & 107.0 & 7.0 \\
\hline Ukraine $^{1 /}$ & 280 & 240 & 221 & 214 & 243,0 & $1.0^{2 /}$ & $100.4^{2 /}$ & $0.4^{2 /}$ \\
\hline Denmark & 169 & 76 & 75 & 74 & 74,0 & 90.0 & 101.5 & 1.5 \\
\hline
\end{tabular}

In 2018, Ukraine the most energy resources has used in ferrous metallurgy - 8608 thousand toe (tons of oil equivalent), food and tobacco industry - 1484 thousand toe, mining - 1463 thousand toe. The pulp and paper industry together with the printing industry consumed 264 thousand toe. It should be noted that in other industries, similar in terms of average annual gross output, this indicator was significantly lower (construction - 197 thousand toe, transport equipment -159 thousand toe, textile and leather industries -62 thousand toe). Thermal energy prevails in the structure of consumption of energy resources of domestic enterprises of the pulp and paper industry.

It accounts for more than $57.2 \%$ of the total consumption of energy resources, while electricity accounts for more than a third and natural gas $-7 \%$. Over the past five years, the consumption of all types of these resources has increased (on average by $2.4 \%$ per year), except for renewable sources, the volume of which is insignificant -0.3 thousand toe, which does not correspond to global trends.

The energy intensity of paper and cardboard production by the pulp and paper industry in 2018 was 0.335 toe/t (Table 2 ).
Table 2. Level and dynamics of energy intensity of paper and cardboard production in Ukraine and some countries of the European Union, 2010-2017, kgoe/t ([21-22]).

\begin{tabular}{|l|c|c|c|c|c|c|c|}
\hline \multirow{2}{*}{ Country } & \multirow{2}{*}{$\mathbf{2 0 1 0}$} & $\mathbf{2 0 1 4}$ & $\mathbf{2 0 1 6}$ & $\mathbf{2 0 1 7}$ & $\mathbf{2 0 1 8}$ & $\mathbf{2 0 1 8}$ to 2010 \\
\cline { 5 - 8 } & & & & & & $\mathbf{k g e e} / \mathbf{t}$ & $\mathbf{\%}$ \\
\hline Portugal & 1279,0 & 942,8 & 869,3 & 931,3 & 960,6 & $-318,4$ & 75,1 \\
\hline Finland & 746,3 & 793,9 & 801,7 & 853,8 & 868,0 & 121,7 & 116,3 \\
\hline Sweden & 661,5 & 709,6 & 797,9 & 798,4 & 796,5 & 135,1 & 120,4 \\
\hline UK & 740,5 & 1009,4 & 2267,9 & 808,9 & 673,6 & $-66,9$ & 91,0 \\
\hline Norway & 654,0 & 677,9 & 563,3 & 552,5 & 600,2 & $-53,8$ & 91,8 \\
\hline Austria & 409,3 & 502,1 & 467,6 & 481,9 & 532,4 & 123,2 & 130,1 \\
\hline Poland & 480,3 & 546,7 & 603,0 & 504,3 & 524,7 & 44,3 & 109,2 \\
\hline Ukraine & 518,2 & 555,0 & 473,9 & 426,8 & 480,4 & $-37,8$ & 92,7 \\
\hline France & 322,8 & 487,7 & 413,4 & 423,9 & 427,2 & 104,4 & 132,3 \\
\hline Italy & 353,1 & - & 383,3 & 453,9 & 406,8 & 53,7 & 115,2 \\
\hline Spain & 340,7 & 464,4 & 387,6 & 377,9 & 405,5 & 64,8 & 119,0 \\
\hline Germany & 372,6 & 371,4 & 358,5 & 349,9 & 354,6 & $-18,0$ & 95,2 \\
\hline Netherlands & 351,8 & 356,9 & 302,7 & 306,5 & 282,4 & $-69,4$ & 80,3 \\
\hline
\end{tabular}

Thus, in comparison with the developed EU countries, Ukraine has a high energy intensity of production in the studied area. Therefore, in 2017, 480.4 kgoe/t was spent on the production of paper and cardboard, while in Italy and Spain - 406-407 kgoe/t, which is $15-16 \%$ less, 
Germany - 354.6 kgoe/t $(26.2 \%$ less $)$ and in the Netherlands - 282.4 kgoe/t (41.2\% less).

In world practice, in order to improve energy efficiency and ensure energy independence, pulp and paper industry enterprises are increasing the use of renewable energy resources. According to the Technology Map of the European Strategic Energy Technology Plan, the average energy consumption in the pulp and paper industry of the European Union countries is between 16 and $30 \%$. At the same time, $55 \%$ of the energy used comes from the combustion of biomass, $38 \%$ - from natural gas [21].

Despite the large reserves of biomass in the agricultural sector and forestry, the pulp and paper industry in Ukraine uses very little renewable resources and lags far behind foreign countries. In 2017, the share of used renewable energy sources in total energy consumption was only $0.1 \%$, while in Austria - 45.1\%, Poland - 46.1, Finland - 57.6, Portugal - 60.7 and Sweden $-65.5 \%$ (Table 3 ).

Table 3. The share of renewable energy resources in total energy consumption in the production of paper and cardboard in Ukraine and individual EU countries, 2013-2018, \% (according to data [23-25]).

\begin{tabular}{|l|r|r|r|r|r|r|r|}
\hline Country & $\mathbf{2 0 1 3}$ & $\mathbf{2 0 1 4}$ & $\mathbf{2 0 1 5}$ & $\mathbf{2 0 1 6}$ & $\mathbf{2 0 1 7}$ & $\mathbf{2 0 1 8}$ & $\begin{array}{c}\text { 2018 to 2013, } \\
\text { p.p. }\end{array}$ \\
\hline Sweden & 62.1 & 64.2 & 95.5 & 66.6 & 66.8 & 65.5 & 3.4 \\
\hline Portugal & 64.7 & 65.8 & 63.3 & 60.8 & 63.2 & 60.7 & -4.0 \\
\hline Finland & 48.9 & 51.5 & 52.9 & 54.7 & 56.1 & 57.6 & 8.7 \\
\hline Poland & 35.8 & 41.4 & 41.7 & 1.9 & 44.5 & 46.1 & 10.3 \\
\hline Austria & 36.5 & 39.5 & 39.1 & 37.1 & 43.9 & 45.1 & 8.6 \\
\hline France & 28.1 & 22.0 & 2.3 & 26.3 & 31.5 & 35.0 & 6.9 \\
\hline Spain & 23.0 & 29.6 & 17.4 & 31.0 & 40.2 & 32.6 & 9.6 \\
\hline UK & 0.0 & 0.0 & 0.0 & 0.0 & 19.9 & 24.0 & 24.0 \\
\hline Norway & 34.3 & 32.0 & 15.4 & 16.6 & 16.2 & 20.5 & -13.8 \\
\hline Germany & 10.7 & 10.9 & 11.5 & 10.9 & 10.8 & 12.7 & 2.0 \\
\hline Netherlands & 0.6 & 0.6 & 0.9 & 0.7 & 0.9 & 0.9 & 0.3 \\
\hline Ukraine & 0.0 & 0.0 & 0.0 & 0.9 & 0.0 & 0.1 & 0.1 \\
\hline Italy & 0.0 & 0.0 & 0.0 & 0.0 & 1.8 & 0.0 & 0.0 \\
\hline
\end{tabular}

The general trend in 2013-2018 was the increase in the share of renewable energy resources in the total energy consumption of the pulp and paper industry, most of countries shown in Table 3. In particular, high growth rates for this indicator are observed in the UK -24 p.p. and Poland - 10.3 p.p. At the same time, the UK pulp and paper industry began to use renewable energy resources only in 2016. The share of Spain increased by almost 10 p.p. $(9.6 \%)$. Austria and France are next with 8.6 p.p. and 6.9 p.p. respectively. In Ukraine, the share of renewable energy sources in 2018 was only $0.1 \%$. Domestic pulp and paper mills began to use renewable energy resources only in 2015 .

\subsection{Factor analysis of energy efficiency in enterprises}

The efficiency of energy resources use in pulp and paper enterprises is influenced by a combination of internal and external factors. Mathematically, the dependence of the efficiency of energy resources in enterprises on organizational, production, energy and other factors should be reflected as a function

$$
f\left(x_{1}, x_{2} \ldots \ldots \ldots x_{n}\right),(1)
$$

where $f$ is a dependent variable, an indicator of energy efficiency,

$x_{1}, x_{2} \ldots \ldots \ldots x_{n}$ - factors influencing the efficiency of energy resources.

For a more detailed analysis of the influence of factors on the efficiency of the use of energy resources in the pulp and paper industry, production, economic, environmental, energy and personnel indicators are systematized and grouped by the authors (Table 4).

Table 4. Groups of indicators for factor analysis of the efficiency of using energy resources of enterprises of the pulp and paper industry.

\begin{tabular}{|c|c|c|}
\hline $\begin{array}{l}\text { Group of } \\
\text { indicators }\end{array}$ & Indicator & Unit \\
\hline \multirow{5}{*}{$\begin{array}{l}\text { Organizational } \\
\text { and production }\end{array}$} & Paper machine productivity & $\mathrm{t} / \mathrm{day}$ \\
\hline & $\begin{array}{l}\text { Efficiency of production } \\
\text { equipment }\end{array}$ & $\%$ \\
\hline & $\begin{array}{l}\text { Wear and tear of production } \\
\text { equipment }\end{array}$ & $\%$ \\
\hline & $\begin{array}{l}\text { Heat losses in production } \\
\text { facilities }\end{array}$ & Gcal \\
\hline & $\begin{array}{l}\text { Heat losses during energy } \\
\text { transportation }\end{array}$ & Gcal \\
\hline \multirow{7}{*}{ Economic } & The price of electricity & $\begin{array}{c}\mathrm{UAH} / \mathrm{kW} \\
\cdot \text { hour }\end{array}$ \\
\hline & The cost of thermal energy & $\begin{array}{c}\text { UAH / } \\
\text { Gcal }\end{array}$ \\
\hline & $\begin{array}{l}\text { Capital investments in energy } \\
\text { saving measures }\end{array}$ & UAH \\
\hline & $\begin{array}{l}\text { Environmental tax rate per } 1 \\
\text { ton of } \mathrm{CO}_{2} \text { emissions into the } \\
\text { atmosphere }\end{array}$ & $\mathrm{UAH} / \mathrm{t}$ \\
\hline & $\begin{array}{l}\text { The share of energy costs in the } \\
\text { cost of paper or cardboard }\end{array}$ & $\%$ \\
\hline & $\begin{array}{l}\text { Costs for the operation of the } \\
\text { energy management system }\end{array}$ & $\mathrm{UAH}$ \\
\hline & $\begin{array}{l}\text { The share of investment } \\
\text { resources attracted through } \\
\text { state and local targeted energy } \\
\text { saving programs }\end{array}$ & $\mathrm{UAH}$ \\
\hline \multirow{5}{*}{ Energy } & Electrical capacity of products & $\begin{array}{c}\mathrm{kW} \cdot \mathrm{hour} / \\
\mathrm{t}\end{array}$ \\
\hline & Heat capacity of products & Gcal / t \\
\hline & Fuel capacity of products & $\mathrm{m}^{3} / \mathrm{t}$ \\
\hline & Heat losses in networks & $\%$ \\
\hline & $\begin{array}{l}\text { Share of renewable energy } \\
\text { costs }\end{array}$ & $\%$ \\
\hline \multirow{3}{*}{ Ecological } & $\begin{array}{l}\text { The volume of } \mathrm{CO}_{2} \text { emissions, } \\
\text { per } 1 \text { toe of fuel consumption }\end{array}$ & $\mathrm{t}$ \\
\hline & $\begin{array}{l}\text { Water intensity of production } \\
\text { of } 1 \text { Gcal of thermal energy }\end{array}$ & \begin{tabular}{|c|} 
thousand \\
$\mathrm{m}^{3} / 1 \mathrm{Gcal}$ \\
\end{tabular} \\
\hline & Share of recycled waste & $\%$ \\
\hline \multirow{2}{*}{ Personnel } & $\begin{array}{l}\text { The amount of remuneration to } \\
\text { employees for saving energy } \\
\text { resources }\end{array}$ & $\mathrm{UAH}$ \\
\hline & $\begin{array}{l}\text { Expenses for measures to } \\
\text { improve the qualifications of } \\
\text { employees }\end{array}$ & $\mathrm{UAH}$ \\
\hline
\end{tabular}




\subsection{Modeling the impact of factors on energy efficiency of enterprises}

Based on the results of the preliminary study, it is possible to formulate a hypothesis about the existence of a relationship between the level of energy costs for the production of 1 ton of paper (cardboard) (resultant sign) and the following indicators (factor signs): paper machines productivity, the share of heat recovery, the share of renewable energy resources, equipment wear and tear, investments in energy saving measures. To confirm the hypothesis, let us group 27 pulp and paper enterprises in Ukraine according to the above performance indicator (Table 5).

Table 5. Dependence of the level of energy consumption for the production of paper (cardboard) on organizational and production, energy and environmental factors at pulp and paper enterprises of Ukraine, 2016-2018.

\begin{tabular}{|c|c|c|c|c|c|}
\hline \multirow[t]{3}{*}{ Indicator } & \multicolumn{3}{|c|}{$\begin{array}{c}\text { Groups of enterprises } \\
\text { in terms of energy } \\
\text { consumption per } 1 \text { ton } \\
\text { of paper, UAH / t }\end{array}$} & \multirow{3}{*}{$\begin{array}{c}\text { On } \\
\text { average } \\
\text { (total) }\end{array}$} & \multirow{3}{*}{$\begin{array}{c}\text { The ratio of } \\
\text { indicators } \\
\text { of group I } \\
\text { to group } \\
\text { III, \% }\end{array}$} \\
\hline & I & II & III & & \\
\hline & \begin{tabular}{|c|} 
below \\
3600
\end{tabular} & $\begin{array}{c}3600- \\
4000\end{array}$ & \begin{tabular}{|c|} 
above \\
4000
\end{tabular} & & \\
\hline $\begin{array}{l}\text { Average ener- } \\
\text { gy consump- } \\
\text { tion in the } \\
\text { group, UAH }\end{array}$ & 3450 & 3820 & 4220 & 3835 & 81.8 \\
\hline $\begin{array}{l}\text { Number of } \\
\text { enterprise } \\
\text { years, units }\end{array}$ & 8 & 11 & 7 & 26 & 114.3 \\
\hline $\begin{array}{l}\text { Productivity } \\
\text { of paper pro- } \\
\text { cessing ma- } \\
\text { chines, } \mathrm{t} / \text { day }\end{array}$ & 232.6 & 196.8 & 156.7 & 194.7 & 148.4 \\
\hline \begin{tabular}{|l|} 
The share of \\
heat recovery, \\
$\%$
\end{tabular} & 36.2 & 28.4 & 22.6 & 29.4 & 13.6 p.p. \\
\hline $\begin{array}{l}\text { Share of re- } \\
\text { newable ener- } \\
\text { gy resources, } \\
\%\end{array}$ & 56 & 33 & 8 & 32 & 48.0 p.p. \\
\hline $\begin{array}{l}\text { Equipment } \\
\text { wear, \% }\end{array}$ & 52 & 68 & 72 & 62 & -20 p.p. \\
\hline \begin{tabular}{|l|} 
Investments \\
in energy sa- \\
ving measu- \\
res, UAH / t \\
\end{tabular} & 125 & 95 & 52 & 88.5 & 240.4 \\
\hline $\begin{array}{l}\mathrm{CO}_{2} \text { emissi- } \\
\text { ons, thousand } \\
\text { tons }\end{array}$ & 18560 & 18756 & 15692 & 17126 & 118.3 \\
\hline \begin{tabular}{|l|} 
Share of re- \\
cycled waste, \\
$\%$
\end{tabular} & 14 & 17 & 12 & 13 & -2.0 p.p. \\
\hline
\end{tabular}

Thus, group I includes enterprises with the lowest energy costs per 1 ton of products - below UAH 3600. In them, the productivity of paper machines is $232.6 \mathrm{t} /$ day, the share of heat recovery is $36.2 \%$, the share of renewable energy resources is $56 \%$, equipment wear is $52 \%$, investments in energy saving measures are 125 $\mathrm{UAH} / \mathrm{t}$.

Group II includes pulp and paper enterprises, in which energy costs per 1 ton of products range from $\mathrm{UAH} 3,600$ to 4,000 . Here, the productivity of paper machines is 196.8 tons / day, the share of heat recovery is $28.4 \%$, the share of renewable energy resources is $33 \%$, equipment wear is $68 \%$, investments in energy saving measures are $955 \mathrm{UAH} /$ ton.

The enterprises of group III have the highest expenses - more than $4000 \mathrm{UAH}$. In such enterprises, the productivity of paper machines is the lowest in comparison with other groups - 156.7 tons / day, investments in energy saving measures - $52 \mathrm{UAH} /$ ton, as well as high wear and tear of production equipment $72 \%$.

In order to identify the direction and closeness of the relationship, we will perform a correlation-regression analysis based on data from 27 enterprise-years of the pulp and paper industry of Ukraine. Taking into account the previously obtained data for the formation of a multivariate regression model, the following main factors are included:

performance indicator $-\mathrm{Y}$ - energy costs per 1 ton of paper or other products, $\mathrm{UAH} / \mathrm{t}$;

factor features:

$\mathrm{x}_{1}$ - productivity of paper machines, $\mathrm{t} / \mathrm{day}$;

$\mathrm{x}_{2}$ - equipment wear, $\%$.

$\mathrm{x}_{3}-$ investments in energy saving measures, $\mathrm{UAH} / 1 \mathrm{t}$

Using the specialized program of statistical data processing Statistica 10, the primary statistical analysis of the initial data was carried out (Table 6).

Table 6. Numerical characteristics of variables.

\begin{tabular}{|l|c|c|c|}
\hline & $\mathbf{Y}$ & $\mathbf{X}_{\mathbf{1}}$ & $\mathbf{X}_{\mathbf{2}}$ \\
\hline Average & 3835 & 84,5 & 326.5 \\
\hline Standard error & 28 & 12,5 & 34.8 \\
\hline Median & 3674 & 86,5 & 315.4 \\
\hline Mode & 2158 & 83.5 & 301.4 \\
\hline Standard deviation & 25 & 16 & 41 \\
\hline Sample variance & 326,4 & 36.2 & 47.5 \\
\hline Excess & 174 & 47 & 65 \\
\hline Asymmetry & 21 & 12 & 11 \\
\hline Interval & 374 & 165 & 465 \\
\hline Maximum & 3985 & 96.8 & 578.1 \\
\hline Minimum & 3145 & 47.2 & 112.4 \\
\hline Sum & 148759 & 165871 & 2165846 \\
\hline
\end{tabular}

According to the results of regression analysis, the following multifactor regression equation is obtained

$$
Y_{x_{1}}=3860-428_{x_{1}}-365_{x_{2}}+65_{x_{3}}
$$

Multiple correlation coefficient $\mathrm{r}=0.728$ indicates a strong relationship, and the coefficient of determination $\mathrm{R}^{2}=0.5298$ shows that almost $53 \%$ of the energy consumption of paper and other paper products is formed under the influence of the above factors included in the model.

Of course, many more factors (social, managerial, environmental, etc.) influence on energy costs. They require further in-depth research. Thus, Tatenda Taodzera, Bhekisipho Twala, Johnson Carroll [26] developed an econometric model in which factors determine almost $90 \%$ of the change in performance. 
Bazylevych et al determined that the profitability of organic production by more than $80 \%$ is determined by such indicators as profitability of fixed assets, the share of agricultural land engaged in organic farming and energy consumption. 10 tons of organic wheat [27].

To increase the energy efficiency of the pulp and paper industry, it is advisable to implement the following measures:

- technical re-equipment, modernization of production equipment, in particular, paper machines in order to increase their productivity;

- increase in investments in energy efficient technologies, reconstruction of the heat supply system, use of renewable energy sources, introduction of energy management systems, reduction of anthropogenic impact.

\subsection{Model of energy modernization of enterprises}

In the context of decreasing reserves of fossil fuels, the introduction of sustainable development principles, the priority task of increasing the energy efficiency of enterprises in the pulp and paper industry is the use of renewable energy resources. Given the natural and climatic conditions, a promising source is the production of heat energy from biomass. The most common types of biomass in Ukraine are:

- agricultural waste - straw, stalks and rods of corn, stalks and husks of sunflower;

- forestry waste - bark, wood chips;

- energy crops - willow, poplar, miscanthus.

In the pulp and paper industry, successful projects for the production of thermal energy from biomass have been implemented. In 2016, a new boiler house with a boiler for burning wood fuel with a moisture content of up to $60 \%$ was put into operation at PJSC "Kokhavian Paper Factory". The average annual heat production is 24 thousand Gcal. Annual consumption of wood chips is about 14 thousand tons / year (40 tons / day at maximum load). As a result of the energy modernization, the enterprise completely abandoned the use of natural gas (over 3 million $\mathrm{m} 3$ / year) and reduced the volume of greenhouse gas emissions.

Despite the obvious advantages, the use of renewable energy resources in the pulp and paper industry is accompanied by a number of risks (Table 7).

To identify the most significant barriers to the use of biomass for heat production at the pulp and paper industry in 2019, the authors conducted an expert survey of industry experts. According to the results of an expert survey, it was found that the use of renewable energy resources in the pulp and paper industry of Ukraine is constrained by the following reasons: lack of funds for capital investments, insufficient development of infrastructure for storing and transporting biomass, low supply of processed biomass, the need to re-equip the internal energy supply system (Table 8).

Thus, $26.9 \%$ of respondents indicated a lack of funds for the re-equipment of heat production, $19.2 \%$ highlighted the problems of the biomass market (weak development of infrastructure for transportation and storage of biomass, low supply in the biomass market), $15.4 \%$ stated the complexity of the technical re-equipment of the main production.

Table 7. SWOT-analysis of the use of renewable energy resources in the pulp and paper industry.

\begin{tabular}{|l|l|l|}
\hline Environment & Positive influence & \multicolumn{1}{|c|}{ Negative influence } \\
\hline Internal \\
environment & $\begin{array}{l}\text { Opportunity to use } \\
\text { waste of own } \\
\text { production. } \\
\text { Cost reduction of 1 } \\
\text { Gcal of thermal } \\
\text { energy. } \\
\text { Reducing the cost of } \\
1 \text { ton of paper. }\end{array}$ & $\begin{array}{l}\text { Increased energy costs. } \\
\text { The need to ensure a } \\
\text { stable supply of energy } \\
\text { resources. } \\
\text { The need to re-equip the } \\
\text { energy supply system. }\end{array}$ \\
\hline External \\
environment & $\begin{array}{l}\text { Introduction of state } \\
\text { incentive } \\
\text { instruments (tax } \\
\text { benefits). } \\
\text { Great potential of } \\
\text { biomass in the } \\
\text { agricultural and } \\
\text { forestry sectors of } \\
\text { Ukraine. }\end{array}$ & $\begin{array}{l}\text { Rising prices for fossil } \\
\text { energy resources (coal, } \\
\text { natural gas) } \\
\text { Strengthening the } \\
\text { regulation of the } \\
\text { anthropogenic impact of } \\
\text { enterprises. } \\
\text { The need to establish } \\
\text { conditions for the supply } \\
\text { of biomass. } \\
\text { Underdevelopment of the } \\
\text { biomass market in } \\
\text { Ukraine. }\end{array}$ \\
\hline
\end{tabular}

Table 8. Distribution of answers of specialists of pulp and paper enterprises to the question "What are the obstacles to the use of renewable energy resources?"

\begin{tabular}{|l|c|c|}
\hline \multirow{2}{*}{\multicolumn{1}{|c|}{ Obstacle }} & \multicolumn{2}{c|}{$\begin{array}{c}\text { Number of } \\
\text { answers }\end{array}$} \\
\cline { 2 - 3 } & people & \% \\
\hline Lack of funds for capital investments & 7 & 26.9 \\
\hline $\begin{array}{l}\text { Weak development of infrastructure for } \\
\text { transportation and storage of biomass }\end{array}$ & 5 & 19.2 \\
\hline Low supply in the biomass market & 5 & 19.2 \\
\hline $\begin{array}{l}\text { The need for technical re-equipment of basic } \\
\text { production }\end{array}$ & 4 & 15.4 \\
\hline High costs for biomass transportation & 3 & 11.5 \\
\hline The need to stop production & 1 & 3.8 \\
\hline $\begin{array}{l}\text { The complexity of the operation of the } \\
\text { equipment }\end{array}$ & 1 & 3.8 \\
\hline Total & 26 & 100.0 \\
\hline
\end{tabular}

To increase the efficiency of energy resources use, we propose a scientific and organizational model of energy modernization of the pulp and paper industry. It aims to replace fossil and fuel energy resources with thermal energy from biomass. It contains a set of economic and organizational tools that are systematically implemented at the regional and local levels and are aimed at the formation of intersectoral logistics, marketing, financial, scientific and information flows (Fig. 4).

The implementation of the proposed scientific and organizational model will contribute to the technical and energy modernization of thermal energy production of the pulp and paper industry, in particular through the combustion of biomass of various types. 

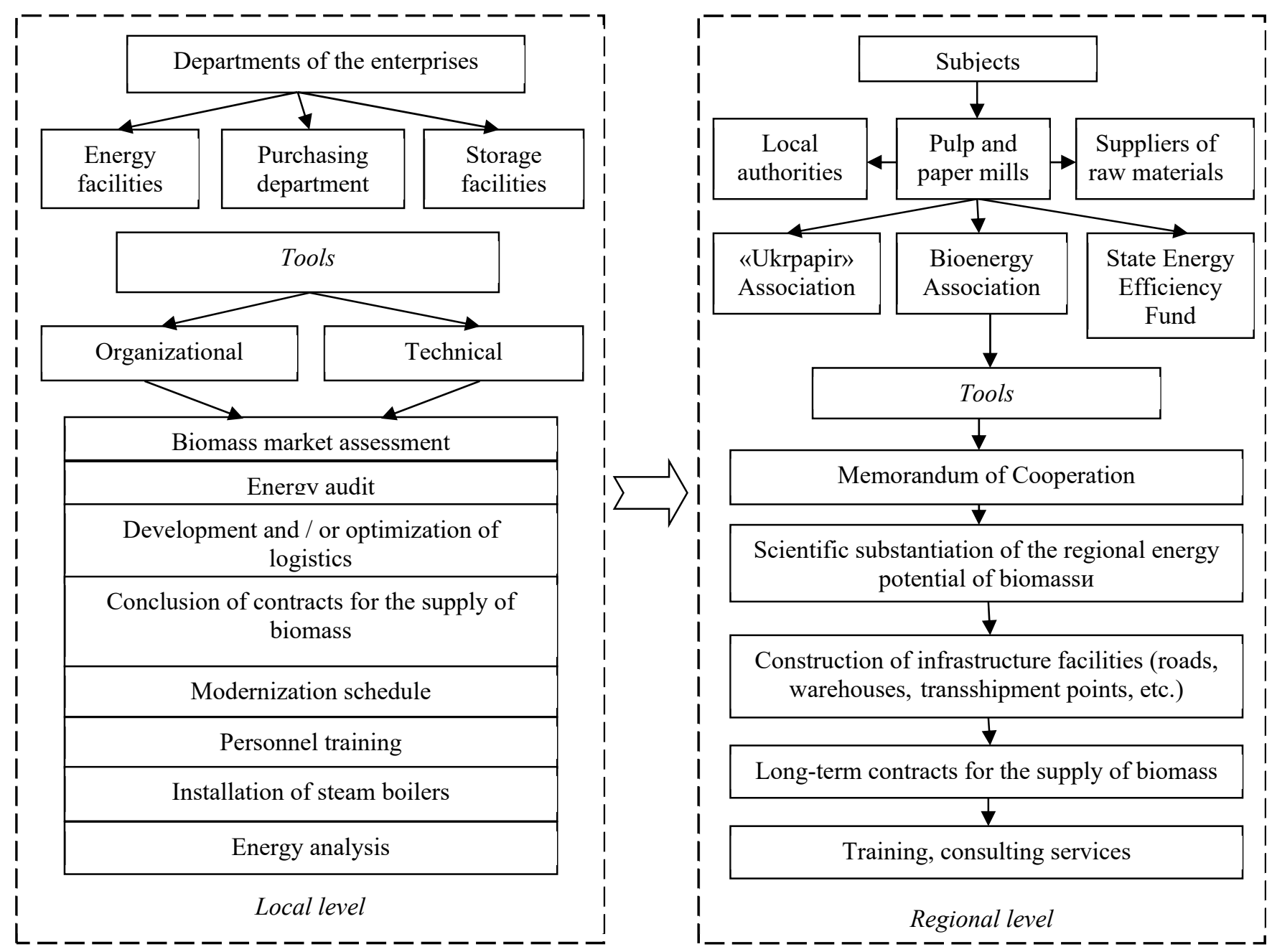

Fig. 4. Scientific and organizational model of energy modernization of the enterprises of the pulp and paper industry of Ukraine for the production of thermal energy from biomass.

\section{Conclusion}

In the context of reforming the energy sector of Ukraine, the introduction of a new model of energy markets, the harmonization of national legislation in accordance with European standards, an urgent requirement of the time is to increase the efficiency of using traditional and renewable energy sources in the production activities of business entities, in particular in the pulp and paper industry. In this industry, energy resources play a decisive technological and economic role in the production of paper and cardboard. Rational, scientifically grounded use of such resources will help reduce energy intensity, production costs, as well as the level of anthropogenic impact on air, water and land resources.

In recent years, at the enterprises of the studied industry, there has been a tendency towards an increase in the volume of consumption of energy resources. In 2018, compared to 2014, the volume of energy consumption here increased by 244 thousand toe, or $12 \%$, including electricity - by 14 thousand toe or $20.5 \%$. At the same time, in the past two years, the growth rate of energy resources consumption exceeded the rate of increase in the volume of production. As a result of rising prices, the share of energy costs in the structure of the cost of paper and cardboard has almost doubled, which has made the enterprises in the industry unprofitable.

To improve the information base for the analysis and assessment of energy consumption, the implementation of innovative measures for energy conservation, and the forecasting of energy costs, it is proposed to apply the developed multivariate correlation-regression model. It describes the dependence (multiple correlation coefficient $=0.728-$ strong relationship) of the level of energy costs for the production of 1 ton of paper or cardboard (effective indicator) on the impact of production (productivity of paper machines, equipment wear) and environmental and economic factors (investments in energy saving measures, share of renewable sources).

To stimulate pulp and paper enterprises for energy modernization using renewable energy resources, it is necessary to implement a set of measures aimed at accumulating financial resources, forming and developing institutional and organizational ties between biomass producers and consumers, and strengthening information and educational training of engineering and management personnel. A scientific and organizational model of energy modernization of enterprises of the pulp and paper industry of Ukraine is proposed. It includes financial and economic, organizational, environmental, regulatory, technological, scientific and educational (personnel) and other tools for implementation at various 
levels of management, in particular, at the regional (biomass exchange, cross-industry research projects for assessing the biomass market, energy efficiency standards, mandatory energy audit and certification of the energy management system) and local (cooperation of producers and consumers of biomass) levels.

\section{References}

1. T.M. Cristino, A.F. Neto, A.F. Branco Costa, Energy efficiency in buildings: analysis of scientific literature and identification of data analysis techniques from a bibliometric study Scientometrics. 114, 1275-1326 (2018). doi:10.1007/s11192-0172615-4

2. H. Zhang, A. Gladisch, M. Pickavet, Z. Tao, W. Mohr. Energy efficiency in communications: Part III IEEE Communications Magazine. 49(8), 52-54 (2011). doi: 10.1109/mcom.2011.5978415

3. I. Khan, F. Hou, H. Le, The impact of natural resources, energy consumption, and population growth on environmental quality: Fresh evidence from the United States of America. Science of the Total Environment 754, (2021). doi:10.1016/j.scitotenv.2020.142222

4. A. Marques Cardoso, J.A. Fuinhas, C. Tomás, Energy efficiency and sustainable growth in industrial sectors in European Union countries: A nonlinear ARDL approach Journal of Cleaner Production 239, (2009). doi:10.1016/j.jclepro.2019.118045

5. S. Akdag, H. Yıldırım, Toward a sustainable mitigation approach of energy efficiency to greenhouse gas emissions in the European countries. Helion 6(3), doi:10.1016/j.heliyon.2020.e03396

(2020).

6. M. Chen, A. Sinha Kexiang, H. Muhammad, I. Shah, Impact of technological innovation on energy efficiency in industry 4.0 era: Moderation of shadow economy in sustainable development. Technological Forecasting and Social Change. 164, 2973-2984 (2021). doi:10.1016/j.techfore.2020.120521

7. S. Ma, Y. Zhang, Y. Liu, H. Yang, Lv Jingxiang, S. Ren: Data-driven sustainable intelligent manufacturing based on demand response for energyintensive industries. Journal of Cleaner Production. 274, (2020). doi:10.1016/j.jclepro.2020.123155

8. V. Burlov, O. Lepeshkin, M. Lepeshkin, Mathematical model for managing energy sector in the region. International Scientific Conference Energy Management of Municipal Facilities and Sustainable Energy Technologies EMMFT 2019. Advances in Intelligent Systems and Computing. 1258, 659-668 (2021). doi: 10.1007/978-3-03057450-5_57

9. C. Cosmi, M. Macchiato, L. Mangialmele, G. Marmo, F. Pietrapertos, M. Salvia, Environmental and economic effects of renewable energy sources use on a local case study Energy Policy. 31(5), 443457 (2003). doi: 10.1016/S0301-4215(02)00073-3

10. C. Ervural Beyzanur, S. Zaim, D. Delen, A two-stage analytical approach to assess sustainable energy efficiency. Energy. 164, (2018). doi:10.1016/j.energy.2018.08.213

11. C. Incekara, S. Ogulata, Turkey's energy planning considering global environmental concerns Ecological Engineering. 102, 589-595 (2017). doi: 10.1016/j.ecoleng.2017.02.033

12. O. Kneysler, U. Andrusiv, N. Spasiv, L. Marynchak, O. Kryvytska, Construction of economic models of ensuring Ukraine's energy resources economy 10th International Conference on Advanced Computer Information Technologies, ACIT 2020. 651-656 (2020). doi: 10.1109/ACIT49673.2020.9208813

13. H. Zelinska, I. Fedorovych, U. Andrusiv, O. Chernova, H. Kupalova, Modeling and prediction of the gas pipelines reliability indicators in the context of energy security of Ukraine CEUR Workshop Proceedings. 2713, 415-433 (2020).

14. I. Zablodska, Y. Akhromkin, A. Akhromki, L. Bielousova, I. Litvinova, World experience in public administration of the transformation of energydependent regions in the context of their sustainable development Problemy Ekorozwoju. 15(2), 235-244 (2020).

15. I. Ivashkiv, H. Kupalova, N. Goncharenko, U. Andrusiv, J. Streimikis, O. Lyashenko, V. Yakubiv, M. Lyzun, I. Lishchynskyi, I. Saukh, Environmental responsibility as a prerequisite for sustainable development of agricultural enterprises Management Science Letters. 10(13), 2973-2984 (2020). doi: 10.5267/j.msl.2020.5.028

16. O. Yemelyanov, A. Symak, T. Petrushka, O. Zahoretska, M. Kusiy, R. Lesyk, L. Lesyk, Changes in energy consumption, economic growth and aspirations for energy independence: Sectoral analysis of uses of natural gas in ukrainian economy. Energies., 12(24) (2019). doi:10.3390/en12244724

17. U. Andrusiv, L. Simkiv, O. Dovgal, N. Demchuk, N. Potryvaieva, A. Cherchata, I. Popadynets, G. Tkachenko, O. Serhieieva, H.Sydor, Analysis of economic development of Ukraine regions based on taxonomy method Management Science Letters. 10(3), 515-522 (2020). doi: 10.5267/j.msl.2019.9.029

18. S. Semerikov, S. Chukharev, S. Sakhno, A. Striuk, V. Osadchyi, V. Solovieva, H. Danylchuk, Our sustainable coronavirus future E3S Web of Conferences. doi:10.1051/e3sconf/202016600001

19. Eurostat (2020), https://ec.europa.eu/eurostat/ data/databas Accessed 15 Dec 2020

20. Statistical year book "Industry of Ukraine in 20112015". State Statistics Service of Ukraine. 2016. 379 p. http://ukrstat.gov.ua Accessed 15 Dec 2020 
21. Energy Efficiency Trends and Policies in the G20 (2020) https://ipeec.org/upload/publication related_language/pdf/295.pdf

22. Energy Efficiency Indicators. International Energy Agency. 2017. https://www.iea.org/publications/freepublications/pu blication/ EnergyEfficiencyHighlights_2017. Pdf Accessed 15 Dec 2020

23. Energy Efficiency 2015 to 2021. Statista. 2018. https://www.statista.com/statistics/379046/worldwid e-retail-e-commerce-sales Accessed 15 Dec 2020

24. Energy Council. https://www.worldenergy.org/ wpcontent Accessed 15 Dec 2020

25. Energy Efficiency in Europe. Assessment of Energy Efficiency Action Plans and Policies in EU Member States. Country report. Finland. 2013. http://www.energy-efficiency-watch.org/ fileadmin/eew_documents/documents/EEW2/Finlan d.pdf Accessed 15 Dec 2020

26. Tatenda Taodzera, Bhekisipho Twala, Johnson Carroll Predicting Engineering Student Success Using Machine Learning (2017). https:/ujcontent.uj.ac.za/vital/access/services/Down load/uj:24160/SOURCE1?view=true

27. G. Kupalova, V. Bazylevych, N. Goncharenko, T. Murovana, J. Grynchuk, Improvement of the Effectiveness of Organic Farming in Ukraine Problems and Perspectives in Managements. 3(15), 97-103 (2017). doi: 10.21511/ppm.15(3).2017.06 